\title{
Agresywność chemiczna płytkich wód podziemnych Wrocławia
}

\author{
Marta Trałka $^{1}$, Magdalena Modelska ${ }^{1}$, Marek Błachowicz ${ }^{1}$
}

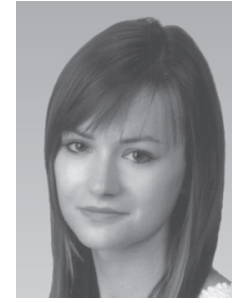

M. Trałka

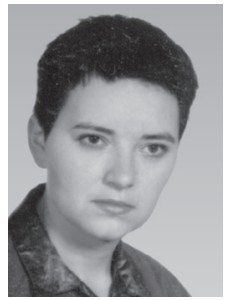

M. Modelska

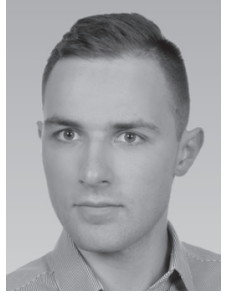

M. Błachowicz

Chemical aggressiveness of shallow groundwater in Wroclaw. Prz. Geol., 69: 901-908; doi: 10.7306/2021.51

A b s tr a c t. Evaluation of the chemical aggressiveness of shallow groundwater for the area of Wroctaw was performed in accordance with the Polish Standard (PN-EN 206+A1:2016-12). This standard requires determination of $\mathrm{pH}$ and concentration of ammonium, magnesium, sulphate and aggressive carbon dioxide in water. The research was carried out on 96 groundwater samples collected in the period March-May 2021 from Holocene, Pleistocene and Neogene deposits. The results show that $58 \%$ of shallow groundwater in Wroctaw was aggressive towards concrete and steel. The slight (XA1), moderate (XA2) and high (XA3) aggressiveness was characteristic for $32 \%, 23 \%$ and $3 \%$ of the analysed waters, respectively. The significant classification factors were the concentrations of aggressive carbon dioxide, sulphate ions and, less significant, $p H$. The presence of magnesium and ammonium ions in groundwater did not have any classification significance because of low concentrations. The occurrence of aggressive groundwater is associated with the environment of river sediments, mainly of Holocene and Pleistocene age. Groundwater beneath till and clay formations, mainly of Pleistocene age, and of anthropogenic banks and dumps shows significantly lower aggressiveness. Aggressiveness of groundwater sampled from the aquifer covered by Neogene clay deposit is not demonstrated. The aggressiveness of Wroctaw groundwater shows a mosaic space character resulting from the geological structure of the city's subsurface formations and is probably also related to the form of land development. The most aggressive ones were associated with green, agricultural and liquidated municipal waste dump areas.

Keywords: chemical aggressiveness, shallow groundwater, Wroctaw

Badania agresywności wód podziemnych są istotnym elementem oceny warunków gruntowo-wodnych niezbędnych w wyznaczaniu obszarów inwestycyjnych. Są szczególnie ważne na obszarach aglomeracji miejskich ze względu na ich szybką i szeroką rozbudowę. Z punktu widzenia warunków gruntowo-wodnych największe znaczenie ma agresywność płytkich wód podziemnych, najczęściej kontaktujących się z fundamentami oraz infrastrukturą konstruowaną $\mathrm{z}$ różnych metali, np. systemami rozprowadzania i magazynowania różnego typu mediów. Ze względu na wysadzinowość gruntu, często nawet pod niewielkie inwestycje, fundamenty projektuje się poniżej głębokości jego przemarzania (w zależności od lokalizacji na obszarze Polski głębokość ta wynosi 0,8-1,4 m) (Gontaszewska, 2010). Agresywność chemiczna wód (korozyjna) jest określana względem betonu i stali, które w kontakcie $\mathrm{z}$ wodą o konkretnych parametrach chemicznych są narażone na szybsze niszczenie i degradację, co często prowadzi do wielu niepożądanych efektów i konieczności częstszej wymiany elementów wykonanych $\mathrm{z}$ tych materiałów (Chruszcz-Lipska i in., 2019). Znajomość parametrów wód podziemnych w zakresie wskaźników powodujących korozję pozwala na dobór odpowiednich materiałów budowlanych i ich odpowiednią izolację, co zapobiega negatywnym skutkom oddziaływania wód. Z formalnego punktu widzenia nie ma obowiązku wykonywania badań chemicznych wody, jednak należy wspomnieć, że zgodnie z zapisami rozporządzenia ministra transportu, budownictwa i gospodarki wodnej w sprawie ustalania geotechnicznych warunków posadawiania obiektów budowlanych (Dz.U. 2012 poz. 463), jeśli zaistnieje potrzeba, należy zbadać parametry fizykochemiczne wód gruntowych dla kategorii geotechnicznych drugiej i trzeciej. Badania agresywności korozyjnej wód podziemnych (gruntowych) względem betonu i stali są regulowane polską normą (PN-EN 206+A1:2016-12). Norma ta wskazuje na konieczność oznaczeń odczynu $(\mathrm{pH})$ oraz stężenia jonów: siarczanowego, magnezowego, amonowego i zawartości agresywnego dwutlenku węgla w celu klasyfikacji wody na trzy środowiska: o słabej (XA1), umiarkowanej (XA2) i silnej (XA3) agresji chemicznej (tab. 1). O ostatecznej klasie agresywności wody decyduje wskaźnik o najgorszych parametrach. Wrocław jako prężnie rozwijająca się aglomeracja stanowi przykład obszaru, gdzie określenie warunków geologiczno-inżynierskich, w tym badania agresywności płytkich wód podziemnych (gruntowych), odgrywa kluczową rolę w budownictwie, geotechnice i inżynierii materiałowej.

\section{OBSZAR BADAŃ}

Powierzchnia Wrocławia wynosi $292,82 \mathrm{~km}^{2}$, z czego $52,2 \%$ stanowią głównie tereny mieszkaniowo-usługowe, komunikacji i aktywności gospodarczej, a pozostałe to obszary zielone oraz rolnicze (Sroczyńska, 2018) (ryc. 1). Nowe inwestycje są planowane nie tylko w centrum miasta, ale również na jego obrzeżach. Warunki występowania płytkich wód podziemnych są bardzo zróżnicowane zarówno pod względem geologii, jak i struktury użytkowania terenu.

Warstwy przypowierzchniowe obszaru Wrocławia tworzą osady rzeczne, rzeczno-lodowcowe i glacjalne holocenu i plejstocenu, a podrzędnie neogenu (ryc. 2). Najmłodsze utwory są związane z główną doliną rzeki Odry i jej dopływami i są wykształcone głównie w postaci piasków i żwirów rzecznych, iłów, mułków oraz namułów osadzonych na tarasach zalewowych. Osadami plejstocenu

${ }^{1}$ Instytut Nauk Geologicznych, Uniwersytet Wrocławski, pl. M. Borna 9, 50-204 Wrocław; marta.tralka@uwr.edu.pl, magdalena. modelska@uwr.edu.pl; marek.blachowicz@uwr.edu.pl 
Tab. 1. Wartości graniczne klas ekspozycji według PN-EN 206+A1:2016-12 dotyczące agresywności chemicznej (korozyjnej) wód podziemnych (gruntowych)

Table 1. Limit values of exposure classes according to PN-EN 206+A1:2016-12 regarding chemical (corrosive) aggressiveness of groundwater

\begin{tabular}{|c|c|c|c|c|}
\hline $\begin{array}{l}\text { Parametr } \\
\text { Parameter }\end{array}$ & $\begin{array}{c}\text { Jednostka } \\
\text { Unit }\end{array}$ & $\begin{array}{c}\text { XA1 } \\
\text { Środowisko chemiczne } \\
\text { malo agresywne } \\
\text { Slightly aggressive } \\
\text { chemical environment }\end{array}$ & $\begin{array}{c}\text { XA2 } \\
\text { Środowisko chemicznie } \\
\text { średnio agresywne } \\
\text { Moderately aggressive } \\
\text { chemical environment }\end{array}$ & $\begin{array}{c}\text { XA3 } \\
\text { Środowisko chemicznie } \\
\text { silnie agresywne } \\
\text { Highly aggressive } \\
\text { chemical environment }\end{array}$ \\
\hline $\mathrm{pH}$ & - & $\leq 6,5 \mathrm{i} \geq 5,5$ & $<5,5 \mathrm{i} \geq 4,5$ & $<4,5 \mathrm{i} \geq 4,0$ \\
\hline $\mathrm{Mg}^{2+}$ & $\mathrm{mg} / \mathrm{dm}^{3}$ & $\geq 300 \mathrm{i} \leq 1000$ & $>1000 \mathrm{i} \leq 3000$ & $>3000$ i do nasycenia \\
\hline $\mathrm{NH}_{4}^{+}$ & $\mathrm{mg} / \mathrm{dm}^{3}$ & $\geq 15 \mathrm{i} \leq 30$ & $>30 \mathrm{i} \leq 60$ & $>60 \mathrm{i} \leq 100$ \\
\hline $\mathrm{SO}_{4}^{2-}$ & $\mathrm{mg} / \mathrm{dm}^{3}$ & $\geq 200 \mathrm{i} \leq 600$ & $>600 \mathrm{i} \leq 3000$ & $>3000 \mathrm{i} \leq 6000$ \\
\hline $\mathrm{CO}_{2}$ agr. & $\mathrm{mg} / \mathrm{dm}^{3}$ & $\geq 15 \mathrm{i} \leq 40$ & $>40 \mathrm{i} \leq 100$ & $>100$ i do nasycenia \\
\hline
\end{tabular}

o genezie wodno-lodowcowej są gliny zwałowe, iły i mułki zastoiskowe oraz piaski i żwiry. Te ostatnie, również o genezie rzecznej, tworzą najwyższe piętra tarasów nadzalewowych doliny Odry. Utwory neogenu to głównie iły, mułki ilaste oraz piaski i żwiry (pliocenu i miocenu) odsłaniające się w zachodniej i południowo-zachodniej części miasta (ryc. 2) (Gizler, 1982; Winnicka, 1985; Winnicki, 1985; Łabno, 1986). Przypowierzchniową warstwę podłoża, zwłaszcza w centrum, stanowią nasypy o genezie antropogenicznej - ściśle związane z historią rozwoju osadnictwa i terenami zabudowy. W średniowiecznej części miasta jest to rodzaj piaszczysto-organicznej mierzwy, a w jego pozostałej części - przesypki piaszczyste i gruzy ceglane o miąższości lokalnie przekraczającej 5 m (Chmal, Traczyk, 2001).
Na obszarze badań pierwsze zwierciadło wód podziemnych jest przeważnie swobodne, a tylko w rejonach występowania słabo przepuszczalnych nasypów oraz glin występuje pod niewielkim ciśnieniem (Żuk, 2000). Przypowierzchniowe wody podziemne występują na głębokości od 7,0 do $0,4 \mathrm{~m}$ p.p.t. W centrum miasta pierwsze zwierciadło wód podziemnych stwierdzono na głębokości 3,22-6,62 m p.p.t. (obserwacje własne $\mathrm{z}$ okresu poboru próbek: marzec-maj 2021). Wahania zwierciadła mają związek z ustalonymi warunkami piętrzenia - zwłaszcza na jazach Wrocławskiego Węzła Wodnego, Elektrowni Wodnej oraz stałych odwodnień (Worsa-Kozak i in., 2008; Worsa-Kozak, Kotowski, 2009). Jakość płytkich wód podziemnych jest narażona na silne wahania ze względu na narastającą antropopresję, szczególnie na obszarach, gdzie

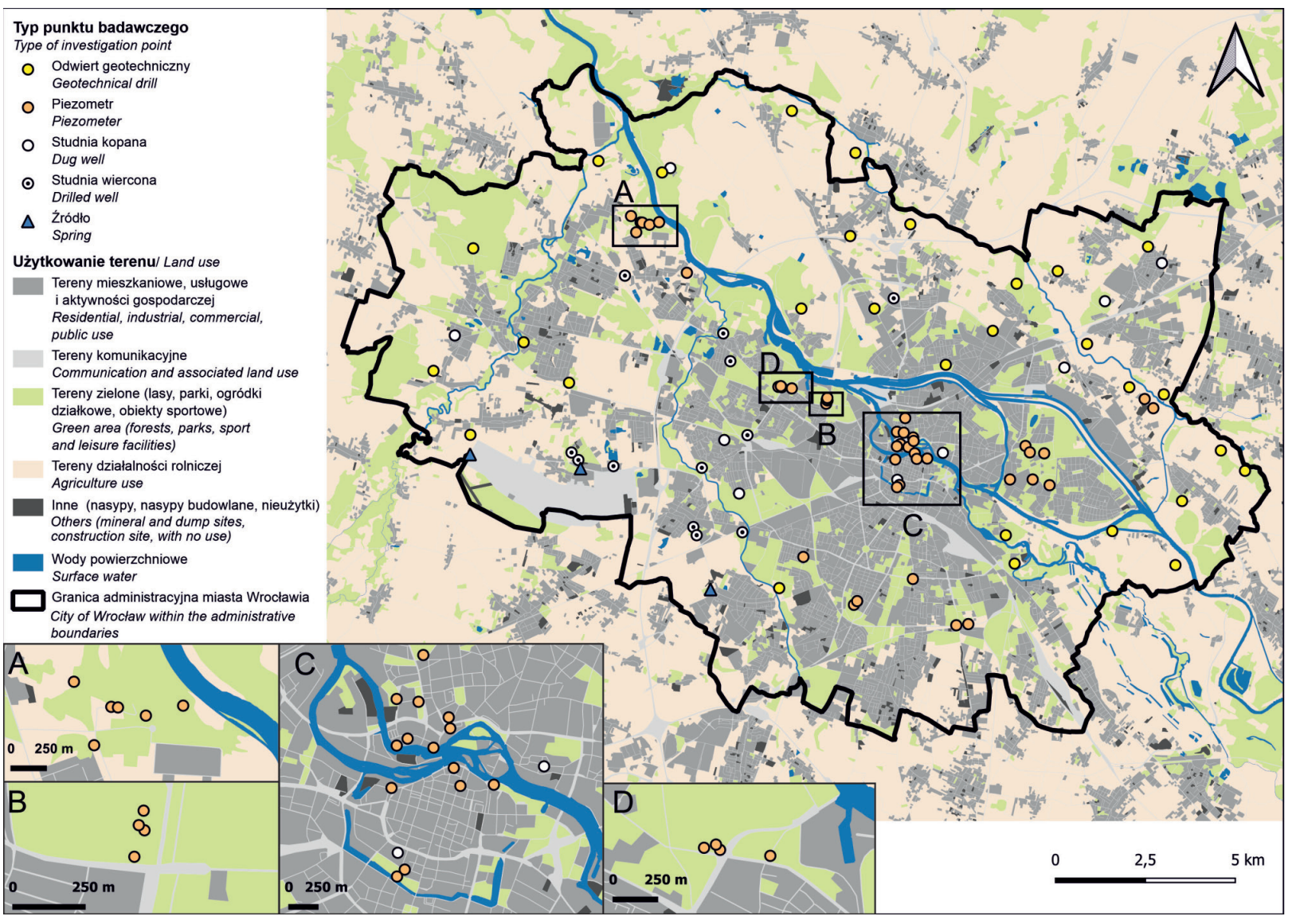

Ryc. 1. Lokalizacja punktów pomiarowych na tle zagospodarowania terenu Wrocławia. Zagospodarowanie terenu: Program Copernicus, Urban Atlas 2018 - zmienione

Fig. 1. Location of measurement points on the background of land development of the city of Wrocław. Land use: Copernicus Programme, Urban Atlas 2018 - modified 


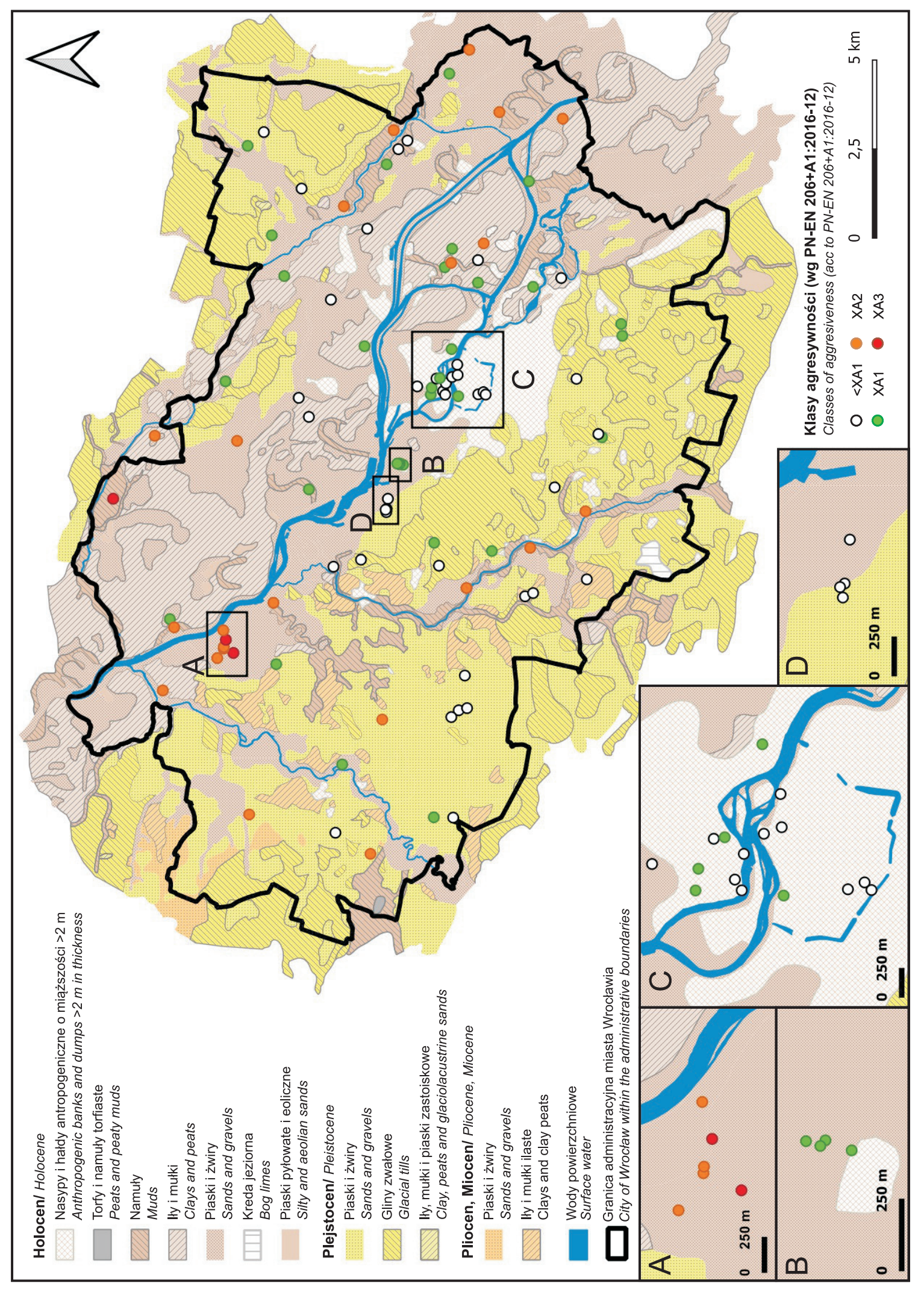

\&్

बิ

$\frac{\overrightarrow{4}}{N}$

त्र

崩

吾

\&

in

욜

$\sum_{\text {i }}$

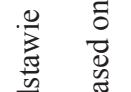

๑

$\ddot{z}$

응

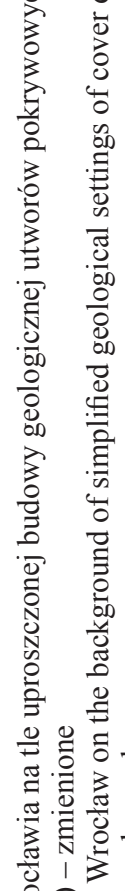

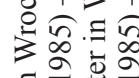

政

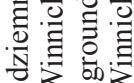

$0 \sum^{\infty} 3$

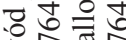

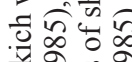

궁

훙

舟

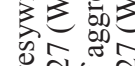

$\operatorname{sen} 4$

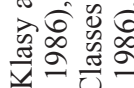

i 8

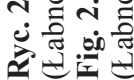


brak jest izolacji tej warstwy od powierzchni terenu. Wody podziemne zurbanizowanej części miasta oraz wybranych, poddanych antropopresji obszarów podmiejskich są silnie zmineralizowane $\left(\right.$ do $\left.2 \mathrm{~g} / \mathrm{dm}^{3}\right)$. Stężenie siarczanów sięga w nich $0,7 \mathrm{~g} / \mathrm{dm}^{3}$, a niekiedy przekracza tę wartość. Obserwuje się również podwyższenie stężenia jonów chlorkowych, azotanowych, manganowych i potasowych. Na obszarach nieobjętych antropopresją wody charakteryzują się podwyższeniem stężenia jonów żelazowych i manganowych, obojętnym odczynem oraz mineralizacją rzędu $700 \mathrm{mg} / \mathrm{dm}^{3}$ (Żuk, 2000).

\section{METODY BADAŃ}

Na potrzeby opisanych badań, w okresie od marca do maja 2021, pobrano 96 próbek płytkich wód podziemnych z piezometrów (43 punkty pomiarowe), studni wierconych (12), studni kopanych (9), źródeł (3) oraz odwiertów geotechnicznych (tymczasowych minipiezometrów o średnicy wewnętrznej $14 \mathrm{~mm}$ ) (29). Punkty te zlokalizowano, W miarę możliwości, na terenie całego Wrocławia (ryc. 1). Pobrane $\mathrm{z}$ nich wody podziemne pochodzą z obszarów o zróżnicowanej budowie geologicznej (piaski i żwiry, iły i mułki, gliny zwałowe, namuły i nasypy), różnym wieku utworów wodonośnych (holocen, plejstocen, neogen) oraz odmiennym zagospodarowaniu terenu (ryc. 1, 2). Każdorazowo przed poborem wód $\mathrm{z}$ otworów wykonywano pompowanie pompką perystaltyczną, a próbki wody pobierano do odpowiednio przygotowanych plastikowych butelek. W czasie prac terenowych dokonywano pomiaru głębokości zwierciadła wód podziemnych (tab. 2) oraz pomiaru temperatury i odczynu wody (wykalibrowanym miernikiem wieloparametrycznym Elmetron CX-461 $\mathrm{z}$ elektrodą $\mathrm{pH}$-metryczną oraz sondą termiczną). W dniu pobrania próbki wody przewożono do Pracowni Geologii Środowiskowej Zakładu Hydrogeologii Podstawowej Instytutu Nauk Geologicznych Uniwersytetu Wrocławskiego i bezzwłocznie poddawano analizom chemicznym. Analizy laboratoryjne parametrów agresywności wód względem betonu i stali obejmowały wskaźniki wymienione w polskiej normie (PN-EN 206+A1:2016-12). Temperatura wód podczas poboru kształtowała się w zakresie $5,3-17,9^{\circ} \mathrm{C}$. Próbki wód przed analizą rozcieńczano od 2 do 50 razy oraz filtrowano przez filtry $0,45 \mu \mathrm{m}$. Oznaczenia stężenia jonów magnezowego, amonowego i siarczanowego wykonano metodą chromatograficzną wysokosprawnym chromatografem cieczowym (HPLC) Waters Alliance Solvent e2695 z użyciem detektora konduktometrycznego Waters $432 \mathrm{z}$ dokładnością do $0,01 \mathrm{mg} / \mathrm{dm}^{3}$. W celu kontroli wyników wybrane próbki poddano analizom instrumentalnym oraz spektrofotometrycznym metodom zalecanym w normie PN-EN 206+A1:2016-12: oznaczenie jonu magnezo-

Tab. 2. Punkty pomiarowe we Wrocławiu z uwzględnieniem głębokości występowania pierwszego zwierciadła wód podziemnych Table 2. Measurement points in Wrocław, taking into account the depth to the first groundwater level

\begin{tabular}{|c|c|}
\hline $\begin{array}{c}\text { Glębokość pierwszego zwierciadla wód } \\
\text { podziemnych [m p.p.t.] } \\
\text { The depth to the first groundwater level }\end{array}$ & $\begin{array}{c}\text { Liczba punktów } \\
\text { Number of points }\end{array}$ \\
\hline $0,0-1,0$ & 16 \\
\hline $1,0-2,5$ & 36 \\
\hline $2,5-3,5$ & 19 \\
\hline $3,5-5,5$ & 19 \\
\hline$>5,5$ & 6 \\
\hline
\end{tabular}

wego metodą miareczkową z EDTA oraz metodą spektrofotometryczną HACH DR/2010 nr 8051 dla jonu siarczanowego. Analizę zawartości agresywnego $\mathrm{CO}_{2} \mathrm{w}$ wodzie wykonano metodą Heyera opartą na reakcji agresywnego $\mathrm{CO}_{2}$ ze sproszkowanym marmurem $\left(\mathrm{CaCO}_{3}\right)$, w wyniku której powstają jony wodorowęglanowe, które poddaje się miareczkowaniu kwasem solnym względem oranżu metylowego (Hermanowicz i in., 1999; Witczak i in., 2013).

Analizę statystyczną wyników badań wykonano z wykorzystaniem pakietu Statistica 13. Mapy wykonano za pomocą oprogramowania QGIS Desktop3.12.1.

\section{WYNIKI I DYSKUSJA}

Płytkie wody podziemne aglomeracji wrocławskiej charakteryzuje znaczne zróżnicowanie parametrów chemicznych odpowiedzialnych za agresywność wód (tab. 3). Wartości średnie i mediany tych parametrów kształtowały się w zakresach typowych dla środowiska poniżej granicy lub $\mathrm{w}$ granicach słabej agresywności (XA1) (tab. 3). Odchylenia od tego trendu polegają na istnieniu wód charakteryzujących się obniżonym odczynem oraz podwyższonym stężeniem przede wszystkim jonów siarczanowych, amonowych oraz agresywnego dwutlenku węgla. Zróżnicowanie wartości pH oraz stężenia jonów magnezowych, amonowych, siarczanowych i agresywnego dwutlenku węgla w analizowanych wodach pochodzacych z utworów zróżnicowanych wiekowo i litologicznie w odniesieniu do normy PN-EN 206+A1:2016-12 przedstawiono graficznie na rycinach $3-7$. Niskie $\mathrm{pH}$ obserwowano w wodach osadów holocenu - przede wszystkim w namułach oraz piaskach i żwirach, a w mniejszym stopniu - w wodach pobranych pod nasypami antropogenicznymi (ryc. 3). Odczyn wszystkich wód podziemnych znajdujących się pod przykryciem utworów gliniastych, iłów i mułków holoceńskich oraz neogeńskich przekraczał pH 6,50 (ryc. 3). Wszystkie badane wody wykazywały małe stężenie jonów magnezowych (środowisko poniżej XA1). Nie zaobserwowano również znacznych różnic wynikających z budowy geologicznej. Nieznacznie podwyższone stężenia jonów magnezowych obserwowano jedynie w wodach pod glinami zwałowymi plejstocenu (ryc. 4). Stężenie jonów amonowych w badanych wodach było bardzo niskie $\left(<0,01 \mathrm{mg} / \mathrm{dm}^{3}\right)$, epizodycznie obserwowano jego podwyższone wartości w wodach pobranych $\mathrm{z}$ utworów holocenu (ryc. 5). Podwyższenie to $\left(>15 \mathrm{mg} / \mathrm{dm}^{3}\right)$ jedynie w przypadku dwóch próbek osiągnęło wartość typową dla środowiska o słabej agresywności (XA1). W obu przypadkach były to próbki wód pobranych w sąsiedztwie nieczynnych składowisk odpadów komunalnych. Pod względem zawartości jonów siarczanowych część badanych wód (występujących w utworach holocenu i plejstocenu) wykazywała przynależność do środowiska o słabej (XA1) lub umiarkowanej agresywności (XA2) (ryc. 6). Stężenie jonów siarczanowych w granicach $200-600 \mathrm{mg} / \mathrm{dm}^{3}$ (XA1) obserwowano w wodach 23 punktów badawczych $(24 \%$ wszystkich badanych wód), natomiast stężenie powyżej $600 \mathrm{mg} / \mathrm{dm}^{3}$ (XA2) - w dwóch badanych punktach $(2 \%)$. Podwyższone stężenie siarczanów w wodach obserwowano w większości ( $\mathrm{z}$ jednym wyjątkiem) na obszarze terenów zielonych oraz terenów działalności rolniczej. Zjawisko to może mieć związek z rozkładem materii organicznej lub też stosowaniem na tych obszarach popularnych nawozów zawierających siarczany (np. siarczan potasu) (Witczak i in., 2013). Znacząca agresywność badanych wód zależała przede wszystkim od obecności w nich agresywnego dwutlenku węgla (ryc. 7). Spośród badanych wód 
Tab. 3. Podstawowe parametry statystyczne wskaźników chemicznych odpowiedzialnych za agresywność w świetle normy PN-EN 206+A1:2016-12 płytkich wód podziemnych Wrocławia

Table 3. Basic statistical parameters of chemical indicators responsible for aggressiveness in the light of PN-EN 206+A1:2016-12 of shallow groundwater in Wrocław

\begin{tabular}{|l|c|c|c|c|c|c|c|c|c|}
\hline $\begin{array}{l}\text { Parametr } \\
\text { Parameter }\end{array}$ & $\begin{array}{c}\text { Jednostka } \\
\text { Unit }\end{array}$ & $\begin{array}{c}\mathbf{N} \\
\boldsymbol{N}\end{array}$ & $\begin{array}{c}\text { Średnia } \\
\text { Average }\end{array}$ & $\begin{array}{c}\text { Mediana } \\
\text { Median }\end{array}$ & $\begin{array}{c}\text { Min } \\
\text { Min }\end{array}$ & $\begin{array}{c}\text { Max } \\
\text { Max }\end{array}$ & $\begin{array}{c}\text { 25 percentyl } \\
\text { 25 percentile }\end{array}$ & $\begin{array}{c}\text { 75 percentyl } \\
\text { 75 percentile }\end{array}$ & $\begin{array}{c}\text { Odchylenie } \\
\text { standardowe } \\
\text { Standard deviation }\end{array}$ \\
\hline $\mathrm{pH}$ & & 96 & 7,30 & 7,24 & 4,85 & 9,05 & 6,75 & 7,89 & 0,78 \\
\hline $\mathrm{Mg}^{2+}$ & $\mathrm{mg} / \mathrm{dm}^{3}$ & 96 & 14,57 & 12,88 & 1,79 & 61,26 & 8,86 & 18,66 & 8,81 \\
\hline $\mathrm{NH}_{4}^{+}$ & $\mathrm{mg} / \mathrm{dm}^{3}$ & 96 & 0,75 & 0,01 & 0,01 & 25,81 & 0,01 & 0,01 & 3,40 \\
\hline $\mathrm{SO}_{4}^{2-}$ & $\mathrm{mg} / \mathrm{dm}^{3}$ & 96 & 164,14 & 110,46 & 0,01 & 926,83 & 63,01 & 212,66 & 158,76 \\
\hline $\mathrm{CO}_{2}$ agr. & $\mathrm{mg} / \mathrm{dm}^{3}$ & 96 & 24,26 & 8,80 & 0,01 & 129,80 & 0,01 & 41,80 & 31,66 \\
\hline
\end{tabular}

w 20 punktach (21\% wszystkich próbek wód) stwierdzono ich niską agresywność (XA1) spowodowaną tym wskaźnikiem, w 21 punktach $(22 \%)$ - agresywność umiarkowaną (XA2) i w trzech punktach $(3 \%)$ - agresywność silną (XA3). Podobnie jak w przypadku jonów siarczanowych, obszary gdzie obserwowano agresywność wywołaną obecnością agresywnego dwutlenku węgla obejmowały tereny zielone i tereny działalności rolniczej. Dwa punkty o silnej agresywności są zlokalizowane w sąsiedztwie nieczynnego składowiska odpadów komunalnych Maślice (rozkład materii organicznej powodujący emisję $\mathrm{CO}_{2}$ i spadek odczynu). Pod względem rodzaju i wieku utworów, w których były obecne tego typu wody, dominowały piaski i żwiry holocenu, w tym te znajdujące się pod namułami. Środowisko XA1, wywołane obecnością agresywnego dwutlenku węgla, zaobserwowano również w wodach piasków i żwirów plejstocenu. Należy podkreślić, że w osadach wodonośnych znajdujących się pod iłami i mułkami neogenu (jedynie 3 punkty badawcze) nie zaobserwowano agresywności chemicznej w przypadku żadnego badanego wskaźnika (ryc. 3-7).
Wartości poszczególnych wskaźników chemicznych stopnia agresywności płytkich wód podziemnych, obserwowane na obszarze Wrocławia, są w większości zbieżne z rezultatami uzyskanymi dla aglomeracji warszawskiej przez Patakiewicza (2016). W obu badaniach czynnikiem o największym znaczeniu dla korozyjności była obecność agresywnego dwutlenku węgla (agresywność węglanowa), a czynnikami niemającymi znaczenia klasyfikacyjnego stężenie jonów magnezowego i amonowego. W przeciwieństwie do obszaru Warszawy, niniejsze badania wykazały niewielkie znaczenie odczynu oraz znaczne stężenie jonów siarczanowych w płytkich wodach podziemnych Wrocławia. Podobnie badania wód podziemnych struktury Horna Nitra na Słowacji (obszaru intensywnej działalności przemysłowej, górniczej i dużego zasiedlenia) wykazały, że największe znaczenie w kształtowaniu agresywności płytkich wód podziemnych mają stężenie jonów siarczanowych i obecność agresywnego dwutlenku węgla, a jony magnezowe oraz amonowe nie mają znaczenia klasyfikacyjnego (Fendekova i in., 2011).Wysokie stężenie agresywnego $\mathrm{CO}_{2}$ wykazała również Porowska (2015) w wo-

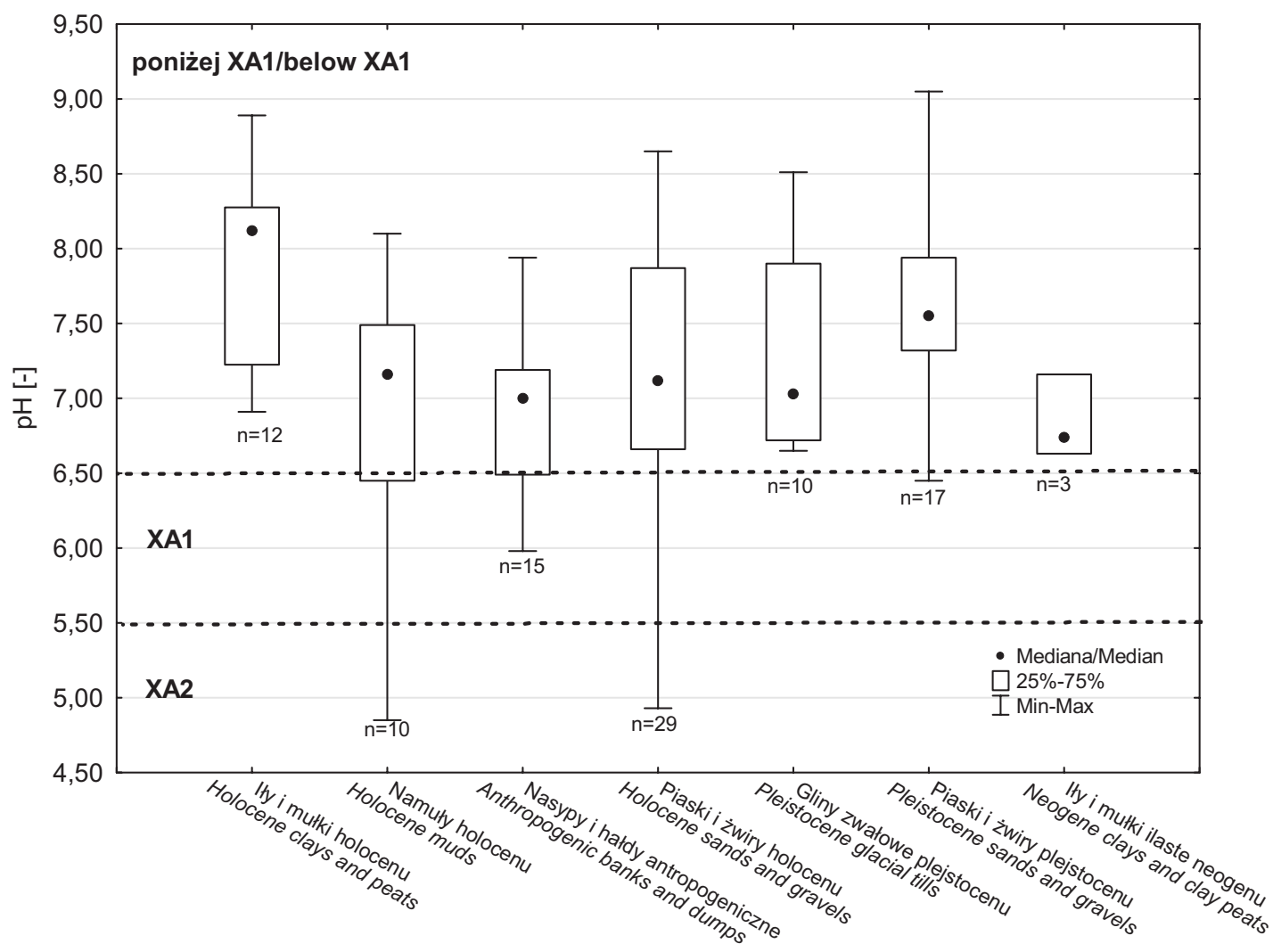

Ryc. 3. pH płytkich wód podziemnych

Fig. 3. The $\mathrm{pH}$ of shallow groundwater 


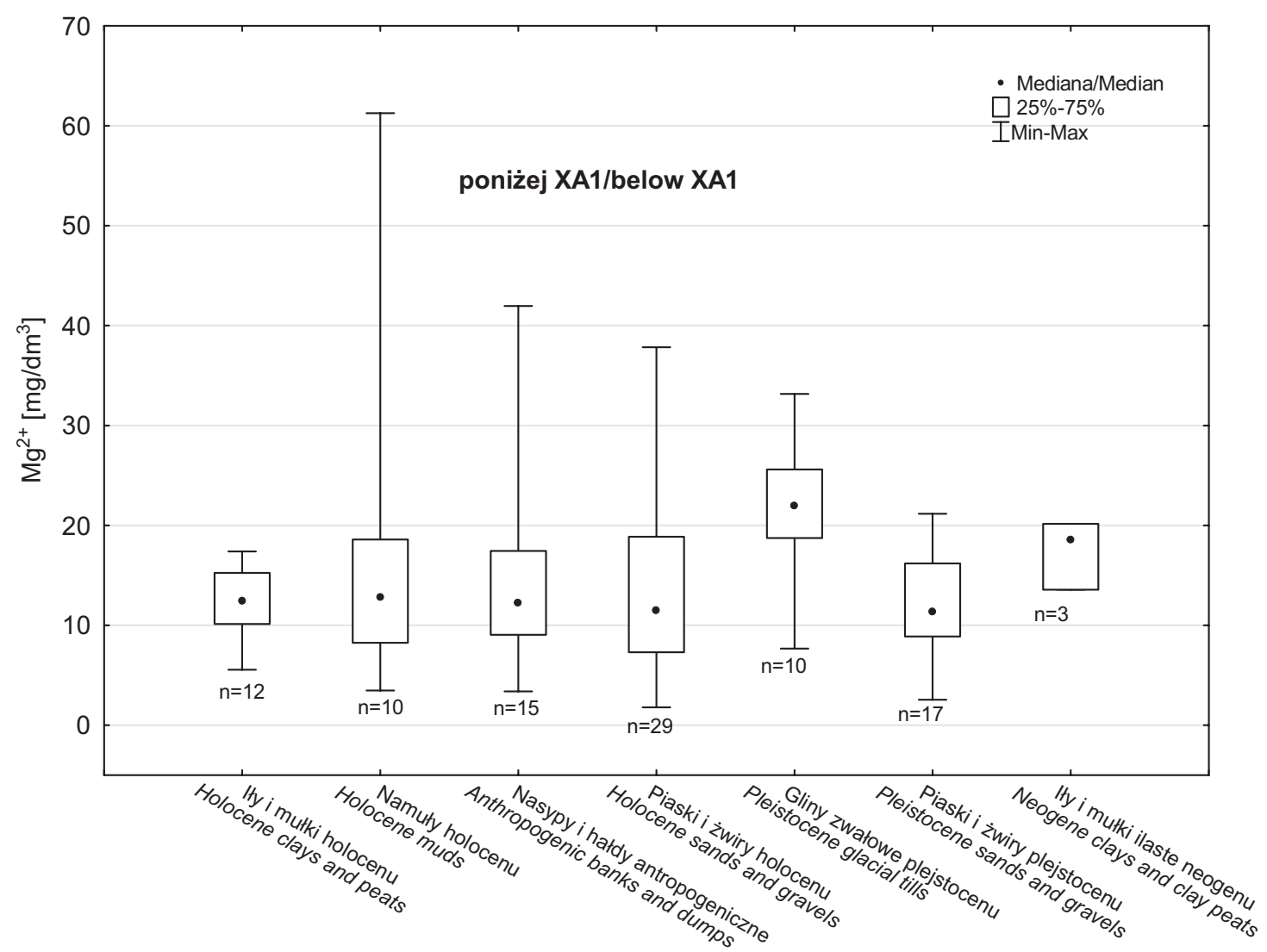

Ryc. 4. Stężenie jonów magnezowych w płytkich wodach podziemnych

Fig. 4. Concentration of magnesium ions in the shallow groundwater

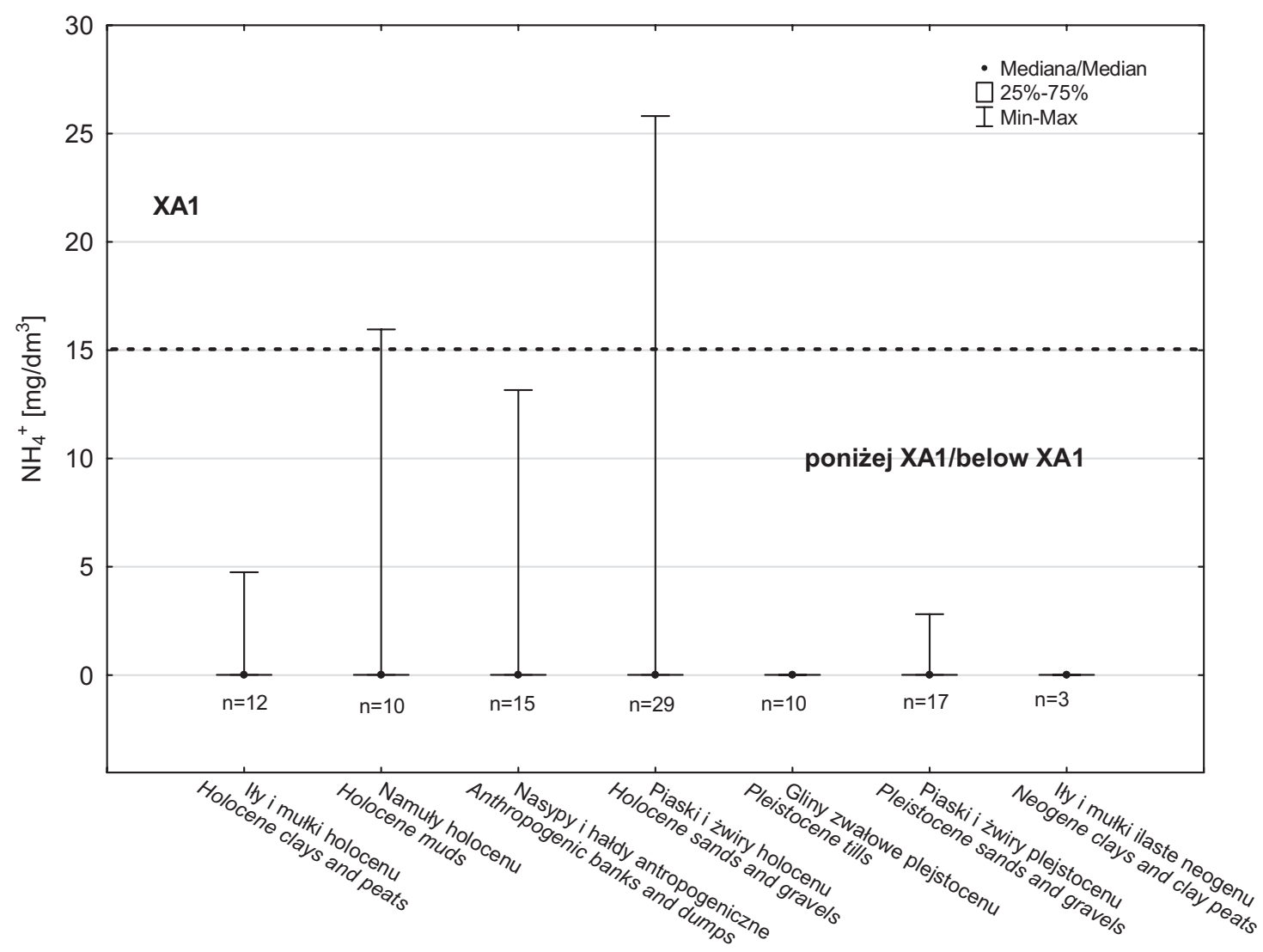

Ryc. 5. Stężenie jonów amonowych w płytkich wodach podziemnych

Fig. 5. Concentration of ammonium ions in the shallow groundwater 


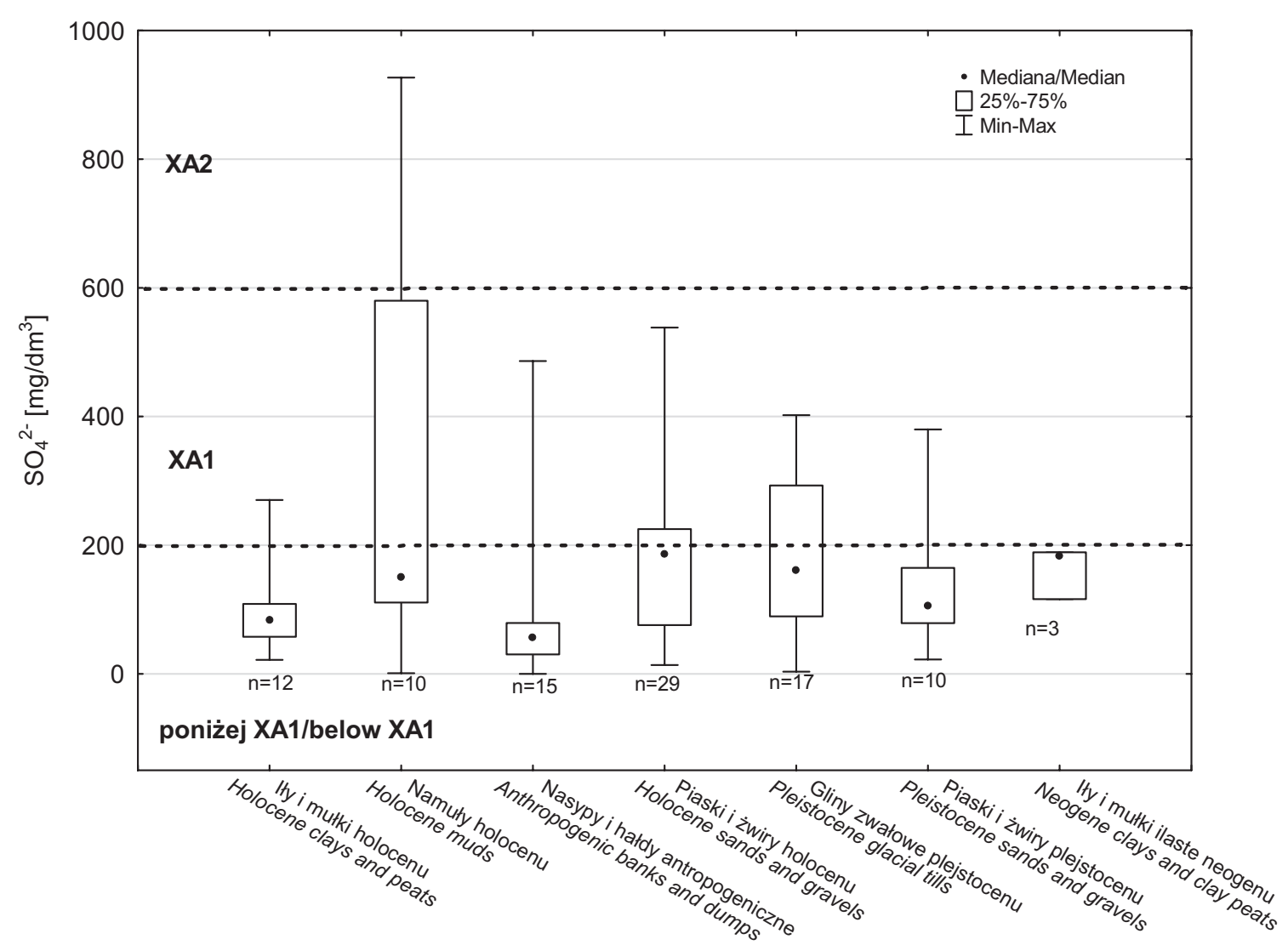

Ryc. 6. Stężenie jonów siarczanowych w płytkich wodach podziemnych

Fig. 6. Concentration of sulphate ions in the shallow groundwater

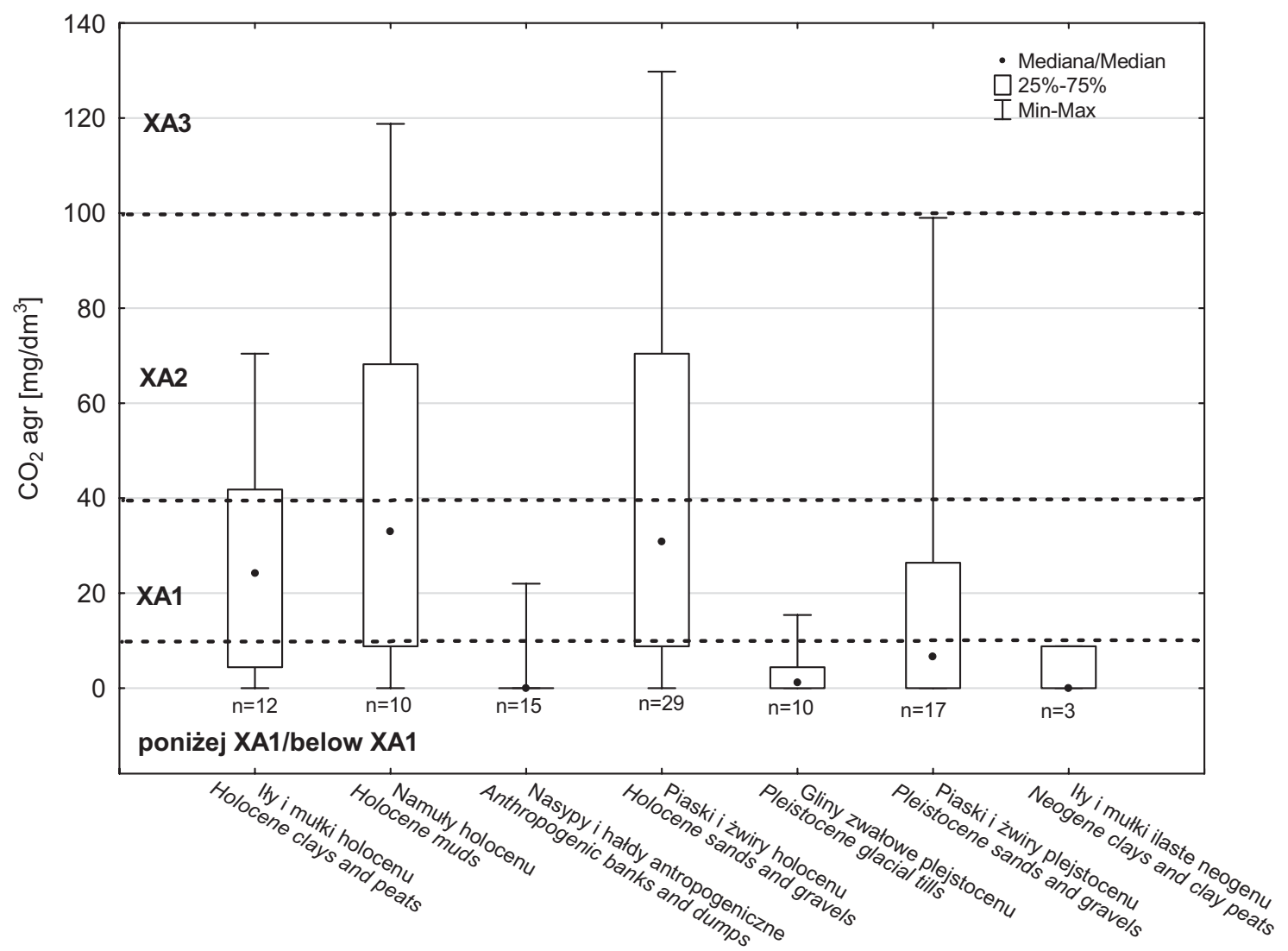

Ryc. 7. Stężenie agresywnego dwutlenku węgla w płytkich wodach podziemnych

Fig. 7. Concentration of aggressive carbon dioxide in the shallow groundwater 
dach podziemnych Otwocka, w tym przypadku stwierdzono jednak istnienie procesu hydrogeochemicznego, który eliminował z wody agresywny $\mathrm{CO}_{2} \mathrm{w}$ bezpośrednim sąsiedztwie zrekultywowanego składowiska odpadów.

Klasyfikując płytkie wody podziemne z uwzględnieniem wszystkich rozpatrywanych wskaźników chemicznych, stwierdzono, że ponad $58 \%$ z nich wykazywało agresywność chemiczną (XA1, XA2, XA3). Nieco poniżej połowy z populacji wód agresywnych $(26 \%$ wszystkich badanych wód) wykazywało agresywność umiarkowaną (XA2) i silną (XA3) (tab. 4). Można uznać, że jest to wartość znaczna, szczególnie w porównaniu z innymi, opisywanymi w literaturze obszarami (Fendekova i in., 2011; Patakiewicz, 2016). Przykładowo dla aglomeracji warszawskiej udział wód niewykazujących agresywności chemicznej był o $10 \%$ mniejszy, a wody wykazujące agresywność umiarkowaną stanowiły zaledwie 13\% płytkich wód podziemnych. W Warszawie nie wykazano również wód o silnej agresywności chemicznej (Patakiewicz, 2016).

Analiza rozkładu przestrzennego stopnia agresywności chemicznej płytkich wód podziemnych we Wrocławiu wykazała, że ma ona charakter mozaikowy i jest powiązana z typem utworów przypowierzchniowych (ryc. 2). Wody niewykazujace agresywności chemicznej stwierdzono głównie w zachodnich, centralnych i południowych rejonach miasta, gdzie dominują utwory plejstocenu i neogenu, a w centrum - także rzeczne osady wieku holoceńskiego i nasypy antropogeniczne. Wody wykazujące agresywność (związane z osadami rzecznymi Odry i jej dopływów) dominowały z kolei we wschodnich i północnych rejonach miasta. Wykazano też niewielką istotną statystycznie zależność korelacyjną między głębokością zalegania zwierciadła wody a stężeniem agresywnego $\mathrm{CO}_{2}(\mathrm{r}=-0,37)$. Może to wskazywać na spadek agresywności płytkich wód podziemnych wraz z głębokością.

Wartości wskaźników odpowiadających za agresywność (jon siarczanowy, agresywny dwutlenek węgla) są również wyraźnie zależne od zagospodarowania terenu (obszary użytkowania zieleni, obszary rolnicze, zlikwidowane składowiska) wpływającego na stopień agresywności chemicznej płytkich wód podziemnych i odpowiadającego w dużym stopniu za mozaikowy obraz tej właściwości wód we Wrocławiu.

\section{WNIOSKI}

Na obszarze Wrocławia dominują płytkie wody podziemne (gruntowe) wykazujące agresywność chemiczną (korozyjność) wobec betonu i stali zgodnie z normą PN-EN 206+A1:2016-12. Czynnikami o istotnym znaczeniu klasyfikacyjnym agresywności chemicznej wód podziemnych jest obecność w wodach podwyższonego stężenia agresywnego dwutlenku węgla, jonu siarczanowego oraz w mniejszym stopniu odczyn. Obecność jonów magnezowych oraz amonowych w próbkach wód nie ma znaczenia

Tab. 4. Klasyfikacja agresywności płytkich wód podziemnych Wrocławia w odniesieniu do normy PN-EN 206+A1:2016-12

Table 4. Aggressiveness classification of shallow groundwater in Wrocław in relation to the PN-EN 206+A1:2016-12 standard

\begin{tabular}{|c|c|c|}
\hline $\begin{array}{c}\text { Środowisko } \\
\text { chemiczne } \\
\text { Chemical environment }\end{array}$ & $\begin{array}{c}\text { Liczba punktów } \\
\text { Number of points }\end{array}$ & $\begin{array}{c}\text { Procent przypadków } \\
{[\%]} \\
\text { Percent of cases }\end{array}$ \\
\hline poniżej XA1 & 40 & 41,66 \\
\hline XA1 & 31 & 32,29 \\
\hline XA2 & 22 & 22,92 \\
\hline XA3 & 3 & 3,13 \\
\hline
\end{tabular}

klasyfikacyjnego, ponieważ ich stężenie kształtuje się zawsze (jon magnezowy) lub prawie zawsze (jon amonowy) poniżej progów klasyfikacyjnych najniższego stopnia agresywności chemicznej (XA1). Występowanie wód agresywnych powiązano ze środowiskiem osadów pochodzenia rzecznego głównie wieku holoceńskiego, podrzędnie plejstoceńskiego. Wyraźnie niższą agresywność wykazują wody podziemne izolowane utworami gliniastymi, ilastymi głównie wieku plejstoceńskiego oraz nasypami antropogenicznymi. Nie stwierdzono agresywności wód w utworach wodonośnych pod osadami ilastymi neogenu. Agresywność wód podziemnych Wrocławia przestrzennie wykazuje mozaikowość wynikającą z budowy geologicznej utworów przypowierzchniowych miasta oraz prawdopodobnie jest również związana $\mathrm{z}$ formą zagospodarowania terenu. Największą agresywność wykazują wody związane z obszarami użytkowania zieleni, rolniczymi oraz w pobliżu zlikwidowanych składowisk odpadów komunalnych.

Autorzy dziękują dr. hab. Sebastianowi Buczyńskiemu za pomoc w pracach terenowych oraz Recenzentom za cenne uwagi, które wzbogaciły treść artykułu. Badania sfinansowano w ramach subwencji badawczej dla Uniwersytetu Wrocławskiego (kd. 76).

\section{LITERATURA}

CHMAL H., TRACZYK A. 2001 - Uwagi o geomorfologii wrocławskiego Rynku, 1. [W:] Rynek Wrocławski w świetle badań archeologicznych, 1. Wratislavia Antiqua, Studia z dziejów Wrocławia, 3: 7-14. CHRUSZCZ-LIPSKA K., WINID B., SOLECKI M.N., MACUDA J., ŁUKANKO Ł., MARUTA M. 2019 - Agresywność korozyjna wód podziemnych w województwie małopolskim, Przem. Chem., 95 (5): 780-783. FENDEKOVA M., MALIK F., KRCMAR D., FENDEK M., ROHACIKOVA A. 2011 - Groundwater aggressiveness assessment according to EN 206-1: data, methods and application on groundwater in the Horna Nitra basin, Slovakia. Environ. Earth Sci., 64: 461-470.

GIZLER H. 1982 - Szczegółowa Mapa Geologiczna Polski w skali $1: 50000$, arkusz 726 - Oborniki Śląskie. Państw. Inst. Geol., Warszawa. GONTASZEWSKA A. 2010 - Właściwości termofizyczne gruntów w aspekcie przemarzania, Ofic. Wydaw. Uniw. Zielonogórsk., Zielona Góra. HERMANOWICZ W., DOJLIDO J., DOŻAŃSKA W. 1999 - Fizyczno-chemiczne badanie wody i ścieków. Wydaw. Arkady: 558.

ŁABNO A. 1986 - Szczegółowa Mapa Geologiczna Polski w skali $1: 50000$, arkusz 763 - Leśnica. Państw. Inst. Geol., Warszawa.

PATAKIEWICZ M.A. 2016 - Agresywność wód gruntowych w świetle wymagań normy PN-EN 206-1. Odniesienia do obszarów zurbanizowanych na przykładzie aglomeracji warszawskiej. Acta Sci. Pol. Architec. 15 (4): 103-112.

POLSKA NORMA PN-EN 206+A1:2016-12 - Beton - Wymagania, właściwości, produkcja i zgodność.

POROWSKA D. 2015 - Ocena agresywności wód podziemnych w rejonie zrekultywowanego składowiska odpadów komunalnych w Otwocku, Prz. Geol., 63 (10/2): 1011-1014.

PROGRAM COPERNICUS, URBAN ATLAS 2018 - https://land.copernicus.eu/local/urban-atlas (dostęp 7 maja $2021 \mathrm{r}$.).

ROZPORZADZENIE Ministra Transportu, Budownictwa i Gospodarki Morskiej z dnia 25 kwietnia 2012 r. w sprawie ustalania geotechnicznych warunków posadawiania obiektów budowlanych. Dz.U. z 2012 r., poz. 463. SROCZYNSSKAA. (red.) 2018 - Studium uwarunkowań i kierunków zagospodarowania przestrzennego Wrocławia, Biuro Rozwoju Wrocławia, Wrocław. WINNICKA G. 1985 - Szczegółowa Mapa Geologiczna Polski w skali $1: 50000$, arkusz 764 - Wrocław. Państw. Inst. Geol., Warszawa.

WINNCKI J. 1985 - Szczegółowa Mapa Geologiczna Polski w skali $1: 50$ 000, arkusz 727 - Trzebnica. Państw. Inst. Geol., Warszawa.

WITCZAK S., KANIA J., KMICIK E. 2013 - Katalog wybranych fizycznych i chemicznych wskaźników zanieczyszczeń wód podziemnych i metod ich oznaczania, Biblioteka Monitoringu Środowiska, Warszawa: 717. WORSA-KOZAK M., KOTOWSKI A. 2009 - Przykład wykorzystania danych z monitoringu wód podziemnych do oceny wpływu elektrowni wodnych na środowisko. Biul. Państw. Inst. Geol., 436: 555-562.

WORSA-KOZAK M., KOTOWSKI A., WARTALSKI A. 2008 - Monitoring stanów wód podziemnych w rejonie Śródmiejskiego Węzła Wodnego we Wrocławiu. Prz. Geol., 56: (4): 302-308.

ŻUK U., 2000 - Objaśnienia do Mapy Hydrogeologicznej Polski w skali $1: 50$ 000, arkusz 764 - Wrocław. Państw. Inst. Geol., Warszawa: 38-39.

Praca wpłynęła do redakcji 14.05.2021 r

Akceptowano do druku 14.07.2021 r. 